\title{
Arginine Measurement
}

National Cancer Institute

\section{Source}

National Cancer Institute. Arginine Measurement. NCI Thesaurus. Code C122095.

The determination of the amount of arginine present in a sample. 